\title{
IIIISGUC.ORG
}

"iş, GÜÇ" ENDÜSTRI iLişKILERI VE INSAN KAYNAKLARI DERGISi

"IS, GUC" INDUSTRIAL RELATIONS AND HUMAN RESOURCES JOURNAL

\section{Collective Responses Of Call Center Workers In The Case Of A Non- Union Worker Organization In Turkey ${ }^{1}$}

\author{
Res.Ass.Şafak TARTANOĞLU \\ Uludağ Üniversitesi, Labour Economics and Industrial Relations Department
}

Ekim/October 2013, Cilt/Vol: 15, Say1/Num: 4, Page: 27-38

ISSN: 1303-2860, DOI: 10.4026/1303-2860.2013.0235.x

Makalenin on-line kopyasına erişmek için / To reach the on-line copy of article:

http://www.isguc.org/index.php? $\mathrm{p}=$ article\&id=507\&cilt=15\&sayi $=2 \& y i l=2013$

Makale İçin İletişim/Correspondence to:

Araş.Gör.Şafak TARTANOĞLU / Email: safaktartan@hotmail.com 


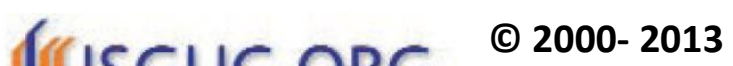 \\ "İ̧̧,Güç" Endüstri iliş̧kileri ve İnsan Kaynakları Dergisi "Işs,Güç" Industrial Relations and Human Resources Journal
}

\author{
Ekim/October 2013, Cilt/Vol: 15, Sayı/Num: 4, \\ Sayfa/Page: 27-38, DOI: 10.4026/1303-2860.2013.0235.x
}

"İş,Güç" Endüstri İlişkileri ve İnsan Kaynakları Dergisi, yılda dört kez yayınlanan hakemli, bilimsel elektronik dergidir. Çalışma hayatına ilişkin makalelere yer verilen derginin temel amact; belirlenen alanda akademik gelişime ve paylaşıma katkıda bulunmaktır.

"İş,Güç" Endüstri İlişkileri ve İnsan Kaynakları Dergisi'nde, 'Türkçe' ve 'İngilizce' olarak iki dilde makale yayınlanmaktadır. "İş,Güç" Endüstri İlişkileri ve İnsan Kaynakları Dergisi, ulusal ve uluslararası birçok indekste taranmaktadır. (Cabell's Directories, Ebsco Socindex, Index Islamicus, Index Copernicus International, Worldwide Political Science Abstracts, Sociological Abstract, Ulakbim Sosyal Bilimler Veritabanı, ASOS Index)

Editörler Kurulu / Editorial Board Aşkın Keser (Uludă̆ University) K.Ahmet Sevimli (Uludă̆ University) Şenol Baştürk (Uludağ University)

\section{Editör / Editor in Chief}

Şenol Baştürk (Uludăg University)

\section{Uygulama / Design}

Yusuf Budak (Kocaeli University)

Tarandığı Indeksler / Indexes ASOS INDEX

CABELL'S DIRECTORIES EBSCO SOCINDEX Index ISLAMICUS Index COPERNICUS Int.

Sociological Abstract

ULAKBİM Sosyal Bilimler

Veritanı

Worldwide Political Science

Abstracts

\author{
Yayın Kurulu / Editorial Board \\ Dr.Şenol Baştürk (Uludă̆ University) \\ Yrd.Doç.Dr.Zerrin Fırat (Uludă̆ University) \\ Doç.Dr.Aşkın Keser (Uludă̆ University) \\ Prof.Dr.Ahmet Selamoğlu (Kocaeli University) \\ Yrd.Doç.Dr.Ahmet Sevimli (Uludağ University) \\ Doç.Dr.Abdulkadir Şenkal (Kocaeli University) \\ Doç.Dr.Gözde Yılmaz (Marmara University) \\ Yrd.Doç.Dr.Memet Zencirkıran (Uludă̆ University)
}

Uluslararası Danışma Kurulu / International Advisory Board

Prof.Dr.Ronald Burke (York University - Kanada)

Assoc.Prof.Dr.Glenn Dawes (James Cook University - Avustralya)

Prof.Dr.Jan Dul (Erasmus University - Hollanda)

Prof.Dr.Alev Efendioğlu (University of San Francisco - ABD)

Prof.Dr.Adrian Furnham (University College London - Ingiltere)

Prof.Dr.Alan Geare (University of Otago - Yeni Zellanda)

Assoc. Prof. Dr. Diana Lipinskiene (Kaunos University - Litvanya)

Prof.Dr.George Manning (Northern Kentucky University - ABD)

Prof.Dr.Mustafa Özbilgin (Brunel University - UK)

Assoc. Prof. Owen Stanley (James Cook University - Avustralya)

Prof.Dr.Işık Urla Zeytinoğlu (McMaster University - Kanada)

Ulusal Danışma Kurulu / National Advisory Board

Prof.Dr.Yusuf Alper (Uludă̆ University)

Prof.Dr.Veysel Bozkurt (Ístanbul University)

Prof.Dr.Toker Dereli (Işık University)

Prof.Dr.Nihat Erdoğmuş (İstanbul Şehir University)

Prof.Dr.Ahmet Makal (Ankara University)

Prof.Dr.Süleyman Özdemir (İstanbul University)

Prof.Dr.Ahmet Selamoğlu (Kocaeli University)

Prof.Dr.Nadir Suğur (Anadolu University)

Prof.Dr.Nursel Telman (Maltepe University)

Prof.Dr.Cavide Uyargil (Istanbul University)

Prof.Dr.Engin Yildırım (Anayasa Mahkemesi)

Doç.Dr.Arzu Wasti (Sabancı University)

Dergide yayınlanan yazılardaki görüşler ve bu konudaki sorumluluk yazarlarına aittir.

Yayınlanan eserlerde yer alan tüm içerik kaynak gösterilmeden kullanılamaz.

All the opinions written in articles are under responsibilities of the authors.

The published contents in the articles cannot be used without being cited. 


\title{
Collective Responses Of Call Center Workers In The Case Of A Non- Union Worker Organization In Turkey ${ }^{1}$
}

\author{
Araş.Gör.Şafak TARTANOĞLU \\ Uludağ Üniversitesi, İİBF, Çalışma Ekonomisi ve Endüstri İlişkileri Bölümü
}

\begin{abstract}
The aim of this paper is to explore the informal collective responses of call centre workers to the working conditions in Turkey ${ }^{2}$, analysing the organizational experience of the Association of Call Centre Workers (ACCW) and to discover the effectiveness and sustainability of it as a new actor in representing the interests of call centre workers. Using focus groups, the emphasis was primarily on the motives of the founders and the members of the Association. This study aims to develop the initial findings. The conditions that generate the forms of dissent and misbehaviour underpinning the informal organization are analysed, alongside the consequences for the sustainability of new forms of organization such as ACCW within the Turkish employment relations context. The emphasis is mostly on their ability to represent the unrepresented ones.
\end{abstract}

Key Words: Collective Response, Call Center, Resistance, Non-Union WorkerOrganization

\section{Özet}

Bu çalışmanın amacı, Türkiye'de çağr merkezi çalışanlarının, çalışma koşullarına karşı oluşturdukları kolektif tepkileri incelemek, Çağrı Merkezi Çalışanları Derneği (ÇMÇ-Der)'nin örgütsel deneyimlerini analiz etmek ve derneğin yeni bir aktör olarak çağrı merkezi çallşanlarının çıkarlarını temsil etmek konusundaki etkinliğini ve sürdürülebilirliğini tartışmaktır. Çalışmada derneğin kurucuları ve üyeleri ile odak grup görüşmeleri gerçekleştirilmiş ve daha önceki çalışmanın bulguları geliştirilmeye çalışılmıştır. Enformel örgütün oluşumunda rol oynayan direniş mekanizmalart ve işverence istenmeyen davranış biçimleri analiz edilmiş, Türk Endüstri İlişsileri sisteminde yeni bir örgütlenme biçimi olarak nitelenebilecek ÇMÇ-Der gibi örgütlerin sürdürülebilirliğine vurgu yapılmıştır. Ayrıca temsil edilmeyen çalışan gruplarını temsil edebilme kapasiteleri sorgulanmuştır.

Anahtar kelimler: Kolektif Tepki, Çağrı merkezi, Direniş, Sendika Dışı Emek Örgütü.

\footnotetext{
${ }^{I}$ This paper is an extended version of the paper presented in 30th International Labour Process Conference in Stokholm in 2012.

${ }^{2}$ See more details. Tartanoglu et al. (2010), “' Call For Truth`: Informalized Collective Responses of Call Centre Workers at Neo-Liberal

Age (The Case of Turkey)", paper presented at the IREC 2010, Fafo, Oslo.
} 
"iş, GÜç" Endüstri İlişkileri ve İnsan Kaynakları Dergisi

"IS, GUC" Industrial Relations and Human Resources Journal
October/Ekim 2013 - Cilt/Vol: 15 - Sayı/Num: 04 Sayfa/Page: 27-38, DOI: 10.4026/1303-2860.2013.0235.x

\section{Call Centres: Modern Workplaces?}

Call centres have had a dominant role in contemporary working life since the early 1990s. When thinking about the organizing practices and resistance mechanisms of call centre workers, it is possible to examine these activities in a dual structure which consists of formal and informal responses. While the formal means of being organized are trade unions and work councils, informal organizational practices are spread out in a wide field from individual ways of coping strategies against the employer to organizing under non-traditional forms of worker organizations.

Most of the existing debate is anchored in the context of advanced post-industrial economies, though important studies have been undertaken in India (Taylor et al. 2009; Bain and Taylor 2008; Taylor and Bain 2005). Yet call centres have become an important sector in developing countries and they are considered as a field which will create employment for the potential of an educated labour force. It is eminently possible to talk about such a trend for Turkey. We also need to recognise that in Turkey collective organizations in the industrial relations system have limited power. Especially among the groups of white collar workers, collective organization practices are seen rarely and these groups generally have not been observed as part of the scope of traditional forms of worker organizations. Therefore, it is necessary to recognise important differences to developed economies from the point of formal organization possibilities.

The general debate on call centres has mostly focused on managerial strategies, labour process, work degradation, working conditions, recruitment and training strategies. There have also been researches about worker resistance and collective organisation. So far, studies about call centres in Turkey are focused on the basic characteristics of the work, as well as the effects of working conditions on workers and human recourses management strategies. However there are few studies about formal and informal resistance practices of call centre workers.
The organization practices in call centres make necessary a different point of view because of the originality of their working forms and high education profile of their workers. Issues of transformation in labour conditions and organization are generally taken together with the concept of "white collar workers". In this approach, it is considered that such employees will keep away from the established collective action mechanisms. But the working conditions in call centres remain far from the traditional expectations of white collars and service relationship. Although call centres workers are generally highly educated, their autonomy at work is weak. Therefore, in the collective action practices it is necessary to consider the temporality which determines the working conditions of call centre workers and to pay attention to the forms of informal organization. The difficulties of organizing in traditional ways also indicate potential representation and voice gaps in the workplace for call centre workers in Turkey, which informal organizations might play some part in filling. We shall return to such gap issues in a subsequent section. Next, the paper will focus briefly on the connection between call centre worker organization and debates on resistance and misbehaviour.

\section{Recent debates about resistance and misbehaviour}

As has been widely observed (see Taylor and Bain, 2003), over the past 30 years, much academic writings about industrial relations and labour process issues have made assumptions about the weakening of organized labour and the marginalization or disappearance of conflict and resistance practices in contemporary workplaces. This was linked to a variety of factors, including the ways in which new technologies and employment practices changed the structure of industrial and work relations.

However such claims have been challenged by mainstream labour process theory (LPT). Traditionally, the view has been taken that the social and economic relations between capital and labour are still a form of 'structured 
antagonism' (Edwards 1990) and it is thus inevitable that modern workplaces are still a contested terrain. Employee resistance is a consequence of the control imperative of managers. Managerial control is never complete and employees find ways of resisting (Collinson and Ackroyd, 2005: 321). Labour process theorists reject that resistance is a result of a rational individual agent trying to achieve their personel goals. Resistance is understood to be inevitable result of the objective exploitation of labour by capital.

Against the suggestions about the "end of resistance" debates, the problem of compliance and opposition at work needs to be reconsidered. In their recent overview Belanger and Thudorez provided a critique of the interpretation of resistance and formulated a conceptual model for forms of employee opposition (2010:138). Their understanding of conflict at work is mostly influenced by LPT, but they they seek to develop an expanded and reinvigorated picture of modes of control and opposition at work. Part of that picture accepts that when looking beneath the surface, a considerable variety of forms of resistance can be seen (Thompson and Ackroyd, 1995: 615).

Debates about worker opposition and resistance in the contemporary world of work are also related to the organizational misbehaviour concept. Ackroyd and Thompson define misbehaviour like 'anthing you do at work you are not supposed to do' and misbehaviour is endemic in contemporary organizations. It is not accurate to envisage the end of the kind of worker pratices that underpin informal worker organization (Ackroyd and Thompson, 1999: 26). Similarly Karlsson defined misbehaviour as "everything that employees do or think that their superiors do not want them to do or think" (2012:17). Another point is misbehaviour shaped and reconfigured by the political, institutional and economic context in which the labour process operates (van den Broek and Dundon, 2010).

Ackroyd and Thompson also discussed this organizational misbehaviour as a form of informal resistance activity in the workplace. The organization not only produces organizational behaviour but produces organizational misbehaviour as well. The question is how and why the organization produces misbehaviour (1999: 8-11). One of the answers to this question is; for many workers who lack formal collective organisation practices, misbehaviours may represent the most available forms of resistance in that kind of situation (van den Broek and Dundon, 2010: 3). Karlsson also pointed out that "seeking dignity when it is under threat is the main mechanism behind employee resistance" (2012: 15).

An important point is how worker resistance to control mechanisms transforms into collective worker action or organization. The empirical coverage of resistance and misbehaviour is incomplete, and there are new terrains in which conflict can be expressed. In addition and lining back to a previous observation, there are few studies about new forms of resistance in developing societies (Collinson and Ackroyd, 2005: 321).

\section{An Unresolved Issue: Worker Representation}

We referred earlier to the practical issue of potential voice and representation gaps, especially for call centre workers in developing economies. The conditions of the appearance of resistance mechanisms in modern workplaces constitute a problematic debate. The rise of new forms of work organization, sometimes linked to so-called 'high performance' work systems have the potential to transform and hide traditional conflicts between capital and labour. Such forms of collective worker actions gradually lose some of their effects and this situation creates a representation gap. Workers have fewer prospects for participation in the workplace.

Worker representation mechanisms historically include collective bargaining and traditional forms of worker organization. The emergence of human resource management practices increase an emphasis on information-sharing, involvement in decision making and quality circle mechanisms (Benson, 2000: 453). Of 
course, it is highly contentious that such mechanisms can fill the representation gap which resulted from the existing conflict in the workplace.

Traditional models of unionism have sometimes become less appropriate for workers in the post-industrial economy. It is highly likely that the future trend will be an increase in non-unionised workplaces. Non-union voice is set to continue to replace more traditional and collectivist employee relations of the past (Dundon and Gollan, 2007:30). In the new lowwage economy, workers lack the long-term relationship to a firm or industry that lies at the core of traditional unionism (Fine, 2005: 158). The weakening of unionism raises the question as to whether workers now have a reduced capacity to initiate issues and articulate grievances (Benson, 2000: 453).

Another point for understanding worker representation is the positions taken by management. The escalation of anti-union managerial strategies (de-collectivising managerial dynamic) for workplace resistance is as important as union decline for understanding resistance mechanisms of workers. Also non-union employee representation arrangements can easily be used for union avoidance by management. The interests of employer may mitigate the interests of the employee, and fail to satisfy employee needs (Dundon and Gollan, 2007:21). Whilst it may be that workers lack the power or inclination to collectively organise, it is evident that worker opposition manifests in a variety of ways. Thinking about 'disorganised' and 'poorly represented workers', the tendency has been to assume that workers respond to managerial control through formal or informal collective-individual voice channels. These workers create some innovative ways and developed tactics in various individualistic as well as semi-collective ways to challenge managerial power and authority (van den Broek and Dundon, 2010).

When the substantial weakening of a system of worker representation founded on trade unions and collective bargaining, the question of how the mentioned representation gap can be filled arises in such debates. The answer is twodimensional. First proposes the revitalization of trade unions. Whilst this is feasible in some contexts, a second identifies a role for new or alternative institutions of worker representation (Heery et al. 2004: 2).

"The decline of trade unions has generated interest in other institutions of worker representation. Arguably, union decline has both created a need and furnished on opportunity for other organizations and movements to fill the representation gap and provide a fresh channel for worker interests" (Heery et al., 2004: 21).

There are different types of organizations such as community unionism, worker centres, or social movement unionism might fill the gap (Stewart et al., 2009) These kind of nontraditional forms of worker organizations provide workers with a range of opportunities for expressing their "collective voice" as well as for taking collective action (Fine, 2005: 420).

\section{Worker Centres}

Worker centres are a good example for the new form of worker organization. They are usually based around ethnic groups and immigrant workers. Especially in America, low wage immigrant workers exist within industries where there are few or no unions through which they can speak. From this point, new type of worker organizations emerged over the past decades. Worker centres have several missions like (Fine, 2005: 418-420); 1) service delivery, 2) advocacy, 3) organizing. Service delivery includes legal representation to recover unpaid wages, worker rights education and access to health clinics, bank accounts and loans. Advocacy includes researching about conditions in low-wage industries, lobbying for new laws and changes in existing ones, working with government agencies to improve grievance processes. And organizing activities includes building ongoing organizations and engaging in leadership development against workers to take action on their own behalf for economic and political change.

These centres are community-based mediating institutions that provide support to communities of low-wage workers. They have a 
social movement orientation and organize around both economic issues and especially immigrant rights. They pursue these goals by seeking to impact the labour market through direct economic action, on the one hand, and public policy reform on the other (Fine, 2007:336-337)

Worker centres have a hybrid structure which combine elements of different types of organizations, and they do not conform to a single organizational model. They can be seen as social movement organizations, labour market institutions or a new organizational form that is a combination of two. They provide services from legal assistance to writing and distributing 'know your rights' handbooks. Most of the centres are not work-site based and unlike unions their focus is not organizing for majority representation in individual worksites. They are organizing workers live or work in the same geographic area instead (Fine, 2005: 426453).

Centres apply a variety of strategic approaches to their organizing and advocacy work. These include bringing direct economic pressure to bear on employers and industries and building political and community support for public policy reforms that require employers and industries to change their behaviour (Fine, 2007: 337).

It can be seen some other models similar to worker centres that organize specific worker groups like call centre workers in developing countries. The next section will explain the informal organizing practices of call centre workers and will explore the concept in Turkish context.

\section{Informal Organization of Call Centre Workers}

The distinctive characteristics of call centre work continue to frame worker dissatisfaction and the form and content of oppositional practices of workers. Most call centres remain as a contested terrain and the patterns of control and compliance are variable (Belanger and Thudorez, 2010: 137). In the labour process, technical control is high but the space for worker resistance and misbehaviour remains even with a high surveillance context (Callaghan and Thompson, 2001: 34).
The formal resistance mechanisms of workers of call centres such as trade unions and company councils are affected by factors like both the industrial relations system of the country and the structure of the labour market. Those factors, on a large scale, shape and limit the demands of workers. Consequently, in addition to the formal practices, workers develop a series of informal ways of misbehaving or resisting. Mulholland (2004) who discussed the collective experiences of PhoneCo workers of Ireland has demonstrated that the resistance strategy of workers came to light in four forms as Slammin, Scammin, Smokin, and Leavin. Slammin, means doing fake sales against administration and supervision technologies, going out of sale scripts in the process of emotional labour of telesales workers; Scammin, describes the work avoidance, absenteeism, sickness of workers; Smokin, and Leavin describes AWOL (leaving work without permission before the shift ends), smoking during the work hours and informal meetings of workers. Smokin is also an expression of collectivity. They discuss some issues about working conditions in these short meetings. Irish call centre workers use these vocabulary when they are resisting undignified conditions (Karlsson, 2012: 131).

In their study highlighting "individual" ways of resistance at work Taylor and Bain (1999) note that the resistance is generally against performance monitoring systems and the competitive structure of team work. They, explain how the individual reactions transformed into collective reactions in the following way: "Where individual, oppositional practices are deeply embedded in particular workplace cultures and are supported, shared or emulated by other disaffected workers, they adopt a quasi-collective form" (1999:112) Parallel to these assertions, as a strategy of coping with being emotionally exhausted and excessive overwork, the importance of informal support of co-workers is also underlined (Deery et. al 2009). Taylor and Bain (2003) also identified humour in the workplace as a form of resistance. Discontent with the experience of task performance, employment conditions and the 'managerial regime' certainly underpin the 
manifestations of workers humour. Humour is often related to manifestations of resistance and sabotage, creating an informal world outside the management control (Taylor and Bain, 2003: 1490; quoted in Linstead, 1985).

If 'representation gap' is defined as the void between the numbers of workers employed and those covered by union recognition and collective bargaining (Bain et al., 2004: 63), we can say that there is a gap in call centres for worker representation. Therefore, resistance mechanisms and coping strategies to the working conditions of call centre workers can be mostly observed in non-traditional forms of worker organization.

Organizational practices of call centre workers differ according to country and the issue of call centre relocation. Worker attitudes to collective organization depend not only the structure of the industrial relations system in that country, but also the conditions in the labour process. Traditional forms of worker organizations trade unions- are not always perceived to be attractive for call centre workers. One of the reasons for this situation constitutes short-term employment relationship. Also employees may associate trade unions with 'blue-collar workers'. Taylor et al. (2009) emphasize that the dynamics of union formation in unorganized call centres and identify that the very heterogeneity of the industry might create difficulties for union organising attempts, particularly in developing economies.

"Joining a union meant losing their jobs, besides creating complications. The competition between teams and between team members also acted as a divisive force" (Noronha and D' Cruz, 2006: 2119).

\section{Methodology}

The main purpose of this study is, regarding the importance of labour process debates about resistance and misbehaviour, to understand and observe possible resistance mechanisms and their potential consequences for informal worker organizations. In this context research focused on resistance strategies and organising practices of call centre workers.

Moving from this purpose, two focus groups were carried out with seven individuals which aimed to analyse the organizational experience of the Association of Call Centre Workers (ACCW) in Turkey. They included the three founders and three members of the Association and a call centre worker who is not member of the Association. Both focus groups were conducted in Istanbul where the headquarter of the Association is also located. The focus groups were completed in two stages, firstly in May 2010 and then in July 2010 and lasted between one and two hours. All interviews were recorded with the permission from all participants.

The focus groups gathered information about the individuals such as their educational status, age and their position within the Association. Participants were also asked about their personal career plans and the place of call centres in these plans; as well as their views on the working conditions within their workplace. In addition to this, the members were requested to discuss their views on their participation process in the ACCW; activities of organization; and the informal resistance experiences of the Association.

\section{The Turkish Context and the ACCW}

In all the circumstances that were explained in the previous sections call centre workers tend to organize in non-traditional forms of organizations. An example for this kind of informal organization is the "Association of Call Centre Workers" (ACCW) in Turkey. ACCW was founded in 2004 as an internet site. At this first stage, more than Association status, it has been designed as a forum based on internet, provides communication between the members. The web site of "call for truth" is not very different from the design of a standard forum site, with new legal developments related with call centres, news about the difficulties which call centre workers have confronted, announcements about the actions and meetings organized by the Association. A distinctive characteristic of the site is that is has no individual information about the founders and other members. Until last year, any information even about headquarters and communication address of the Association has not been seen. 
There can be various reasons of this secrecy. First, the daily life actions against labour organizations tend to be negative in Turkey. Alternatively, in Turkish labour relations, labour organizations traditionally may create harsh reactions of employers. Second, studies about call centres have proved that monitoring and surveillance practices were intense. In this connection it is necessary to highlight that control mechanisms in call centres are also rigid. All these conditions illustrate why the Association was managed semi-formally and has informal organization and resistance methods. The logo of the ACCW which is used during the actions has been designed as a "ghost" who can represent these conditions. The founders have experienced some problems about relations which they have created over site. There were people who they haven't seen their faces but they have supported.

In relation to our previous discussion, the ACCW can be seen to operate in many ways as a "worker centre". For example, it aims to help workers learn about their rights, organize and act collectively to improve their conditions. In this sense the ACCW also helps to fill a representation gap in similar ways.

The main difference between the worker centres, community unions and the association is; worker centres and community unions organize an ethnic group, immigrants, or geographical communities, but "Association of Call Centre Workers" organize individual group of call centre workers. Worker centres are mostly based on ethnicity, rather than occupation or industry (Fine, 2005: 428; Stewart et al, 2009: 8).

Worker centres have attracted workers who are often the hardest to organize and are acting as “organizing laboratories" (Fine, 2005: 452- 453). It is possible to argue that the association is based on the same purpose. Organizing call centre workers is a difficult job because of the temporary structure of employment. In Turkey, in the field of union organization the principle is the branch of activity. It is impossible to find trade unions out of their branch of activities in according to labour law in Turkey. For example workers, who are working in call centre of a bank, can only organize in the banking sector. Call centres are not in the framework of any branch of activity in the related law. Furthermore, the efficiency of trade unions is decreased in Turkey as in other countries. In these circumstances organizing in a non-trade union organization is easier for these workers.

Like a number of worker centres, the Association has 500 or less formal members. Many centres don't view membership size as a central measurement of organizational power, and have talked about "quality" over "quantity" (Fine, 2005: 444). As one the founders of the Association said; the important point is to include workers into the process. Formal membership status has not a crucial role for the multitude perspective of the association.

Loose member structure differentiates the ACCW`s potential to gain members from the principles of traditional unionism. In traditional unions members are gained generally by the power of collective actions, union propaganda and interaction at workplace. But in ACCW membership occurs by connection of workers who lives individual problems related with the sector and working conditions and largely via the internet.

Like worker centres, ACCW began without an idea of membership requirement. Unlike trade unions norms of operation such as mandatory membership and dues are outside their realm of experience. They have never been dependent upon workers to support them financially (Fine, 2007: 342).

ACCW has developed some influence among call centre workers by using original kinds of collective actions. Those action practices which were constituted on secrecy at the beginning, in time have paved the way for increasing awareness about working conditions of call centres. Again in time, besides informal kinds of actions, the Association has developed more traditional labour resistances. On the other hand, recently the ACCW have started to organize panels and conferences on certain problems such as mobbing in call centres. Association supports a call centre worker during her legal struggle, who has been forced 
to quit from her job after a long mobbing process in the workplace.

\section{Collective Actions of the Association}

Individual insufficiency against hard working conditions of call centre workers is the main element which determines the action practices. But this unusual situation makes the standard form of collective action difficult. Poor working conditions, after a point, cause some reactions which are not systematic and not collectively decided. According to Pelin:

"After a while the routine of the work we did became very boring as much as I feel myself as a robot. I was talking with 130 persons in 5 hours. And it was impossible that these conversations to be out of standard scripts."

To Mehmet resisting to the working conditions in the case of call centre workplaces is easier because of the lack of long-term relationship with the firm. Workers mostly don't see this job as a part of their career path.

Many call centre workers can give individual responses against the routines. But although these reactions do not have continuity, they influence workers to think more sympathetically about collective action. Pelin says:

"It is necessary to behave collectively with the people whom we don't know in teams which continuously change. Many times we are asked to participate in activities which are not genuine and directed to this target. After a point, this becomes a torment for you and also you are boring from this. For example there is a routine which supported by the management as celebrating the birthdays of the people who take place in the same team. As time passes, I have become hating from participating to these celebrations. When I was asked to participate I was saying that I am working."

ACCW considered these kinds of individual reactions as the frame of its own action policies. The Association made its first action by using these methods. And Sevgi says:

“... We have decided a date and hour. Everybody went to the closest coin box telephone cabin. Earlier we had prepared a manifesto. Everybody had read this text and talked about the web site..."

Because of the strong effect, the "call attack" has begun to consider as the main action form of ACCW. When a problem or violation of law happened in any call centre, in order to attract attention to this, the Association has preferred to start call attacks against that call centre. A recent call attack has been started by the Association last year. This was to support four workers employed in the Burger King call centre, who were fired because of their trade union membership. The campaign announced from the website of the Association invited the public to call Burger King and read the following script to protest the event and to support those workers (www.gercegecagrimerkezi.org):

"Hello, I am calling for supporting call centre workers like you, not for ordering a burger. I know what is happening there and I can't eat that burger anymore. And I won't eat them until your rights are accepted by the employer. You are not alone.."

After introducing itself to the target group (call centre workers) via call attacks and web site, another method of action of ACCW in order to threaten the management and have made known it by the workers is "pasting stickers". These stickers produced from the ghost logo which ACCW accepted as symbol are at the same time preferred as a way of propaganda of the Association. Aslı says:

"In fact the place where first time I have heard the name of the Association was the smoking room of call centre. While I was smoking there I have seen the sticker of the Association. When I went smoking room another day I have seen that the sticker had been pulled up. Later, sticker has been pasted again. Then I have started to think that something happens there and there are other people whom I can share my uneasiness"

ACCW's practice nearest to collective action is protesting, which they carried out in the reward night organized by the Association of Call Centre Employers. A group of Workers' Association managers hold a press statement at entrance of the field which the ceremony was carried out. It is possible to consider this action as the indication of ACCW is a well organized group. It also expresses a determination to be visible directly to the employers. This action also has attracted the attention of the press and increased the concern, expectation and sympathy among the call centre workers towards the Association. This action is important for Ekin also: 
"This reward ceremony protest became a threshold in the name of gaining the sympathy of workers, in the name of creating a pro-labour public opinion."

Another recent action is a reward night which is prepared by the Association. The main purpose of this action is protesting the employer's reward ceremony and contacting more call centre worker to organize them. This action is called "Big Ear Rewards of the Year". The categories are like "the worst workplace", "mobbing special award", "discrimination against woman workers special award"... Call centre workers can enter a website and join to the survey about the categories. So workers decide which workplace is the worst or they can declare their dissatisfaction about the working conditions.

\section{Relations with Trade Unions}

The membership structure of the association differentiates from trade unions. Unlike formal traditional organizations members are not only call centre workers, but also constituted from unemployed workers who are fired from call centres as they are an association member.

The intent of ACCW about being a trade union is not clear. Ekin says:

"We have contacted with trade unions. But we have seen that because we are an informal group our actions are actions which trade unions do not want to make."

Consequently, it is possible to say that the founders have continued their ties consciously loose with trade unions. Ekin says:

"Against some problems, when we are constrained to solve the problem, we are directing people to the related trade unions which we are in contact. Because a problem related with overwork can be solved only by a trade union."

"Actions we did or we wanted to do, are the ones which the trade unions will be constrained. The objective of trade unions is to have more members, but our goal is completely different. Because the call centres have shift system. While they can't even speak with each other; we have no direct chance of organizing those workers. So it is impossible for us to follow a method which will satisfy us with only being member of trade union. We have followed a more open way of organization by making announcement and showing ourselves at the web site..."

The Association specifies the main problem of call centre workers as being unorganized. In this sense the 'raison d'etre' of the association is to organize the unorganized workers and to articulate their voice against the employer. At this point, it is believed that being a non-trade union worker organization is the most effective way to achieve these aims.

Mehmet explain this situation like this:

"To be a trade union or to be an association is not very important. All of these are the multitude perspective. You are taking an attitude against a group. The important point is to include the people into the process. As an association it is important that how much we undertake what we have said; how much we can change the culture which comes into being there..."

\section{Concluding Remarks}

Moving from the importance of labour process debates such as resistance and misbehaviour, we have tried to understand the possible resistance mechanisms of call centre workers in this paper. In the context of decline of traditional trade unions, there is a potential voice and representation gap for workers. Nonunion employee voice mechanisms which can be seen in collective forms, replace the traditional worker organizations especially in developing countries. ACCW constitutes an example for these kind of organizations.

The main purpose of this study is to direct attention to a non-trade union organization in a developing country like Turkey. "Association of Call Centre Workers" can be considered as an interesting model and, with reference to Worker Centres, a kind of 'organising laboratory'. Because it is a model for a webbased and new generation organization and it has developed unusual action forms, the ACCW has an original place in the labour movements of our era.

At the beginning, the ACCW has arisen from the need of pioneer founders who shares the similar problems, to be able to give collective responses against the difficult working conditions. It developed some influence among call centre workers by using original kinds of collective actions. Those practices which were constituted in secrecy at the beginning, in time have paved the way for increasing the wider social visibility of working conditions of call centres.

As an ongoing process this study aims to analyze the consequences for the sustainability 
of new forms of organisation such as ACCW within the Turkish employment relations context. Further research will focus on these questions:

-What are the conditions that create the organization?

- What are the conditions that sustain the nontrade union organizations?

As a result of this further investigation it will enable to discuss the capacity of sustainability of the Association as a non-trade union organization.

\section{References}

Ackroyd, S. and P. Thompson (1999) Organizational Misbehaviour, London: Sage.

Bain P., P. Taylor, K. Gilbert and G. Gall (2004) “Failing to Organize- or Organizing to Fail? Challenge, Opportunity and the Limitations of Union Policy in Four Call Centres", in G. Healy, E. Heery, P. Taylor and W. Brown (eds.), The Future of Worker Representation, Basingstoke: Palgrave, pp. 62-81.

Bain, P. and P. Taylor (2008) "No Passage to India? Initial Responses of UK Trade Unions to Call Centre Offshoring", Industrial Relations Journal, 39(1), pp.5-23.

Belanger, J. and C. Thudorez (2010) "The Repertoire of Employee Opposition" in Paul Thompson and Chris Smith (eds.) Working Life-Renewing Labour Process Analysis, Basingstoke: Palgrave Macmillan, pp. 136-159. Benson, J. (2000) "Employee Voice in Union and NonUnion Australian Workplaces", British Journal of Industrial Relations, 38(3), pp. 453-459.

Callaghan, G., and P. Thompson (2001) "Edwardes revisited: Technical Control and Call Centres", Economic and Industrial Democracy, 22 (1), pp.13-36.

Collinson, D. and S. Ackroyd (2005) "Resistance, Misbehaviour and Dissent" in S. Ackroyd, R. Batt, P. Thompson and P.S. Tolbert (eds.) The Oxford Handbook of Work and Organization, Oxford: Oxford University Press, pp. 305-326.

Deery, J. S., R. D. Iverson and J. T. Walsh (2009), "Coping Strategies in Call Centres: Work Intensity and the Role of Co-Workers and Supervisors", British Journal of Industrial Relations, 48(1): 181-200.

Dundon, T. and P. J. Gollan (2007) "Re-Conceptualizing Voice in the Non-Union Workplace", International Journal of Human Resource Management, 18(7), pp 11821198.

Edwards, P.K. (1990) "Understanding Conflict in the Labour Process: The Logic and Autonomy of Struggle" İn D. Knights and H. Willmott (eds.), Labour Process Theory, London: Macmillan.

Fine, J. (2005), "Worker Centers: Organizing Communities At the Edge of the Dream", http://heinonline.org, Accessed on: 5.12.2012.
Fine, J. (2007), “A Marriage Made in Heaven? Mismatches and Misunderstandings Between Worker Centres and Unions", British Journal of Industrial Relations, 45(2), pp. 335-360.

Heery, E., G. Healy and P. Taylor (2004) “Representation at Work: Themes and Issues", in G. Healy, E. Heery, P. Taylor and W. Brown (eds.), The Future of Worker Representation, Basingstoke: Palgrave, pp.1-36.

Karlsson, J. Ch (2012), Organizational Misbehaviour in the Workplace- Narratives of Dignity and Resistance, New York: Palgrave: MacMillan.

Linstead, S. (1985) "Jokers Wild: The importance of humour and the maintenance of organisational culture", SociologicalReview, 33(4), pp. 741-767.

Mulholland, K. (2004) "Workplace Resistance in an Irish Call Centre: Slammin' Scammin' Smokin' an' Leavin'”, Work, Employment and Society, 18(4), pp. 709-724.

Noronha, E. and P. D'Cruz (2006) “Organizing Call Centre Agents: Emerging Issues", Economic and Political Weekly, 27.05.06, pp. 2115-2121.

Stewart, P., J. McBride, I. Greenwood, J. Stirling, J. Holgate, A.Tattersall, C. Stephenson and D.Wray (2009) "Introduction", in J. McBride and I. Greenwood (eds.), Community Unionism-A Comparative Analysis of Concepts and Contexts, Basingstoke: Palgrave Macmillan, pp. 3-21. Tartanoglu, S., S. Bastürk and B.F. Emirgil (2010) " 'Call For Truth': Informalized Collective Responses of Call Centre Workers at Neo-Liberal Age (The Case of Turkey)", paper presented at the IREC 2010, Fafo, Oslo. Taylor, P. and P.Bain (1999) "'An Assembly Line in the Head': Work and Employee Relations in the Call Centre", Industrial Relations Journal, 30(2), pp. 101-117.

Taylor, P. and P. Bain (2003) "'Subterranean Worksick Blues': Humour as Subversion in Two Call Centres", Organization Studies, 24(9), pp. 1487-1509.

Taylor, P. and P.Bain (2005) "India Calling From Far Away Towns: The Call Centre Labour Process and Globalization", Work, Employment and Society, 19(2), pp. 261-282.

Taylor, P., P. D'Cruz, E. Noronha and D. Scholarios (2009) "Indian Call Centres and Business Process Outsourcing: A Study in Union Formation", New Technology, Work and Employment, 24(1), pp. 19-42.

Thompson, P. and S. Ackroyd (1995) "All Quiet on the Workplace Front? A Critique of Recent Trends in British Industrial Sociology", Sociology, 29(4), pp. 615-633.

van den Broek, D. and T. Dundon (2010) "(Still) Up to No Good: Reconfiguring the Boundaries of Worker Resistance and Misbehaviour in an Increasingly NonUnion World", International Labour Process Conference, Rutgers University, New Jersey, 15-17 March. www.gercegecagrimerkezi.org 